\title{
Modelling the Relationship between Linked-In Usage and Social Capital Formation
}

\author{
By Najmul Hoda ${ }^{1}$, S L Gupta ${ }^{2}$, Mobin Ahmad ${ }^{3}$, Utkarsh Gupta ${ }^{4}$
}

\begin{abstract}
The main purpose of this study is to test if the use of social networking sites (SNSs) results in any perceived social capital for the users. Putnam's classification of social capital into bridging and bonding social capital is used for the study. The first objective of the study was to study the demographic and behavioral profile of LinkedIn users. The second objective was to test the model describing the relationship between the constructs intensity of LinkedIn usage and the two types of social capital. A structured questionnaire that included standard scales for measuring the constructs was shared on various social media platforms. The model was analyzed using PLS-SEM in R software. The results confirmed all the three hypothesized relationships and also validated the overall model. This study contributes to the validation as well as extension of social capital theory in SNS. Further, the results throw light on the new applications of SNS by the industry.
\end{abstract}

Keywords: Social networking sites; LinkedIn; Social capital theory; Online social capital; Social networking; PLSSEM; R Script; Robert Putnam

\section{Introduction}

Social Networking Sites (SNSs) are internet based online applications that allow the users to perform all possible networking activities as in a traditional offline network. Boyd \& Ellison (2007) defined SNS as, "web-based services that allow individuals to construct a public or semi-public profile within a bounded system, articulate a list of other users with whom they share a connection, and view and traverse their list of connections and those made by others in the system". These sites offer similar networking opportunities as the traditional networks (S. M. Edwards, 2011; Kaplan \& Haenlein, 2010). They differ from traditional computer mediated communication channels like emails as they allow "streaming" of contents (Treem \& Leonardi, 2012). There is now a range of such networking sites offering different types of networking services. These social networking sites help in connecting with known as well as unknown users registered on that platform (Pang, 2017). The penetration of SNSs has increased substantially in a short span of time and at a very fast rate. Researchers have been focusing on the latent benefits of these SNSs because these platforms are effectively allowing the users to maintain their "social bonds" (Ellison \& Vitak, 2015; Liu et al., 2016). Some of the most popular social networking sites are Facebook, Twitter, LinkedIn, Twitter, Instagram and Snapchat (Kellogg, 2020). As per a report (Statista, 2020), the total number of SNS users worldwide is more than 3.8 billion as on July 15, 2020.

Social capital as a concept has been studied in multiple areas including business and

\footnotetext{
1 Department of Business Administration, Umm Al-Qura University, Makkah, Kingdom of Saudi Arabia 2Department of Management, Birla Institute of Technology - International Center, Muscat, Sultanate of Oman 3Department of Mathematics, Jazan University, Jazan, Kingdom of Saudi Arabia

${ }^{4}$ School of Business, University of Connecticut, USA
} 
entrepreneurship (Yuan et al., 2018). It has also been postulated by researchers to have intrinsic quantifiable benefits - in the form of access to resources, employment opportunities, and creation of human and financial capital (Kwon \& Adler, 2014). Social capital also results from the investment in "human relationships" (Lin, 2017). This investment primarily involves time but may also include other resources (Saxton \& Guo, 2020). An important property of this capital is that it may be accumulated and is subject to the financial rules of depreciation or destruction (Svendsen \& Svendsen, 2003).

The role of social networking in the creation of social capital has been established in several studies (Ellison et al., 2007; Liu et al., 2016b; Song \& Vinig, 2012). Some studies have mentioned that the social capital thus formed may differ from that of traditional network (Resnick, 2001; Wellman et al., 2001). There are also arguments against the formation of social capital through SNS (Lőrincz et al., 2019). Neves (2013) highlighted the need for more studies to confirm the relationship between SNS usage and social capital formation. Recent studies have focused on the process by which online social capital accumulated through SNS. Facebook users have been consistently targeted for the research on online social capital. Few studies are available on other SNSs such as LinkedIn, WeChat, etc. (Brown \& Michinov, 2019; Ellison et al., 2011; Kahai \& Lei, 2019; Pang, 2018b). This study, therefore, aims to empirically test if SNS usage predicts the perceived social capital among users with focus on LinkedIn users. It further aims to study the detailed profile of LinkedIn users. The results will help in harnessing significant benefits of SNS accruing for various stakeholders. This study will also validate the social capital theory in context of SNSs. The remaining sections of the paper are organized as follows. Section 2 discusses the theoretical background and hypotheses development. Research Methodology is presented in Section 3. Discussion based on results is done in Section 4. The last section concludes the study and also discusses the limitations and future directions.

\section{Theoretical Background and Research Hypotheses}

\subsection{The social capital theory}

Farr (2004) mentioned that social capital theory was first presented by Lyda J. Hanifan in 1916. A classical definition of social capital as given by Bourdieu \& Wacquant (1992). Social capital is defined as,

"the sum of the resources, actual or virtual, that accrue to an individual or a group by virtue of possessing a durable network of more or less institutionalized relationships of mutual acquaintance and recognition" (Bourdieu \& W acquant 1992, p119).

Many other definitions of social capital have seemed to concur on the properties of social capital that it results from network and is a form of goodwill, a resource and an investment (Kwon \& Adler, 2014; Lin, 2017). The explanation of social capital put forward by Robert D. Putnam has been one of the most popular (Putnam, 2000; Williams, 2006a). He classified social capital into two main types namely the bridging social capital and the bonding social capital. Bridging social capital, also known as weak ties in which the network participants may be "work colleagues, casual acquaintance, or complete strangers" (Pang, 2018b). The main focus in these ties are on information sharing (Brown \& Michinov, 2019; Ellison \& Vitak, 2015). The bonding social capital or the strong ties is a result of more intense and close relationship among individuals (Darcy, 2014; Ellison et 
al., 2007; Williams, 2006b). This capital develops in homogenous groups (Tiwari, Lane, \& Alam, 2019) and manifests in the form of "emotional, social and physical support" accruing from closer ties (Ellison et al. 2014; Weiqin, et al., 2016; You \& Hon, 2019).

\subsection{Social networking sites and social capital}

The literature review indicates that there has been significant addition of studies that deal with online social capital or social capital formation through SNS usage (Burke \& Kraut, 2016; Wang et al., 2016; Williams, 2019). These studies have largely supported the theory that social capital is formed through SNS usage as well. Liu et al. (2016a) support the theory that social capital is formed online as well arguing that SNS overcomes the distance barrier. However, there are reasons to believe that social capital accrued online may be different from offline social capital (Haythornthwaite, 2002; Subrahmanyam et al., 2008).

Earlier studies focused on the formation of bridging social capital formation through SNS and found that it is comparatively higher than offline social capital ( Ellison et al., 2007; Liu et al., 2016b). Later, the investigations on bonding social capital confirmed that SNS produce it too (Phua et al., 2017b; Steinfield et al., 2008; Subrahmanyam et al., 2008). There are now many studies that confirm the creation of both types of capital namely bridging (weak ties) as well as bonding (strong ties) accrue simultaneously within online social networks (Arampatzi et al., 2018; Pang, 2018b; Tiwari et al., 2019a).

\subsection{Research questions and hypotheses}

Demographic profile, age, gender, experience with the SNS, culture have been some notable independent variables studied in the related research (Ahmad, et al., 2016; Ellison et al., 2007; Lee, et al., 2014). It is therefore pertinent to study the demographic profile of the SNS users in this study.

RQ1 What is the demographic profile of LinkedIn users?

SNS user behavior like the time spent, number of connections and the attitude towards SNS also influence on social capital formation (Chang \& Zhu, 2012; Ellison et al., 2007; Liu et al., 2016b). We therefore analyze the various behavioral aspects of the LinkedIn users to answer the following research question.

RQ2 What is the behavioral profile of LinkedIn users?

Intensity of using social networking sites has been used in a number of studies and found to be positively related to online social capital (Cheng et al., 2019; Horng \& Wu, 2020; Huang \& Liu, 2017; Vanden Abeele et al., 2018). We therefore formulate the following hypotheses to examine the relationship between the SNS usage intensity and the two types of social capital.

Hypothesis 1. SNS usage intensity positively affects the perceived bridging social capital Hypothesis 2. SNS usage intensity positively affects the perceived bonding social capital

Relationship between bonding and bridging social capital have been examined in earlier studies (Haghighatian \& Sanatkhah, 2014). We hypothesize that the strong ties developed in the SNS might have a direct influence on the loose ties or the bridging social capital. Therefore, we formulate the hypothesis.

Hypothesis 3. Bonding social capital positively affects the perceived bridging social capital 


\section{Research Methodology}

\subsection{Research Model - LinkedIn usage intensity and social capital}

Based on the hypotheses formulated in Section 1, the research model is presented in Figure 1. The model illustrates the relationship between the independent variable namely SNS usage intensity and the dependent variables namely bonding and bridging social capital. Partial Least Squares Structural Equation Modelling (PLS-SEM) was used to test the model in R software version 3.6.2. PLS-SEM is a variance based approach (MateosAparicio, 2011) and has several benefits that make it fit for use in this study. One major benefit of this technique is that it better estimates "the causal relationships between latent variables" (Wetzels et al., 2009). This technique does not require multivariate normality, measurements are reflective and is capable of modelling with a small sample size.

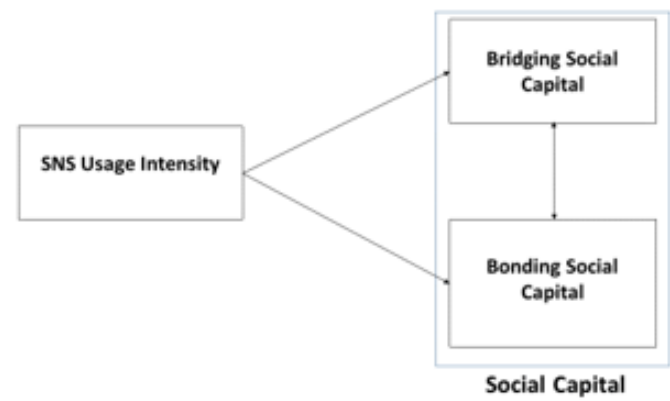

Figure 1. Hypothesized model.

\subsection{Sampling and data collection}

LinkedIn users formed the population for this study. A structured questionnaire was published on Google Forms and shared on LinkedIn as well as other social networking sites like WhatsApp, Facebook and also by emails. A total of 112 responses were received over a period of three months from October 2019 to January 2020. The data was captured in MS-Excel. It was found that some responses for the sections that dealt with the measures of LinkedIn intensity and online social capital were missing. As a result, 89 responses were found usable for testing the model. The details of the sample are explained in Section 4.1.

\subsection{Measures}

\subsubsection{Demographic Profile}

The demographic profile of LinkedIn users was assessed on the basis of age, gender, educational qualification, discipline, work experience, profession and location. These were included as categorical questions in the research instrument.

\subsubsection{Behavioral profile}

In order to assess the behavioural profile, two components of the Ellison's Facebook Intensity Scale were used. These items were number of connections and average daily usage of the SNS. Additionally, the experience of using LinkedIn was also included. These items were asked as categorical questions in the online questionnaire. 


\subsubsection{SNS Usage Intensity}

The construct SNS usage intensity was measured using a part of the Ellison's Facebook Intensity Scale. The Likert questions that measured the emotional connectedness of Facebook users were adapted to measure usage intensity of LinkedIn users. The respondents rated five statements on a seven point Likert scale. These questions were: I am proud to tell people I am on LinkedIn; LinkedIn has become part of my daily routine; I feel out of touch when I haven't logged onto LinkedIn for a day; I feel I am part of my school community through LinkedIn; I would be sorry if LinkedIn shuts down. The reliability of the scale is described in Section 5.

\subsubsection{Measures of Social Capital}

Internet Social Capital developed by Williams (2006a) was used to measure the two types of social capital. This has been earlier validated in several studies (Appel et al., 2014; Guo et al., 2014; Liu et al., 2016b). The scale includes ten questions each to measure bonding and bridging social capital. We used a seven point scale as it increases the accuracy (Finstad, 2010). The reliability of the scale is described section 3.

\section{Results}

\subsection{Demographic profile of LinkedIn users}

The demographic profile of the respondents is given in Table 1. The main characteristics of the sample is that it has majority males, age group 26-40 and educated. The differences in the distribution on some parameters found in the current study compared to the actual may be due to the network structure of the researchers. It is an important area of future research to explore the network structure formed through SNSs.

Table 1. Demographic profile

\begin{tabular}{|c|c|c|c|}
\hline \multirow{2}{*}{ Attributes } & \multirow{2}{*}{ Category } & \multicolumn{2}{|c|}{ Total } \\
\hline & & $\mathrm{N}$ & $\%$ \\
\hline \multirow{2}{*}{ Gender } & Male & 92 & 82.1 \\
\hline & Female & 20 & 17.9 \\
\hline \multirow{4}{*}{ Age groups } & $15-25$ & 13 & $\overline{11.6}$ \\
\hline & $26-40$ & 69 & 61.6 \\
\hline & $41-55$ & 27 & 24.1 \\
\hline & $\geq 56$ & 03 & 2.7 \\
\hline \multirow{5}{*}{ Education } & Primary & 0 & 0.0 \\
\hline & Secondary/Intermediate & 0 & 0.0 \\
\hline & Graduate & 33 & 29.5 \\
\hline & Post Graduate & 50 & 44.6 \\
\hline & Graduate(Bachelor) & 29 & 25.9 \\
\hline \multirow{6}{*}{ Profession } & Never Employed & 02 & 1.8 \\
\hline & Currently Not Employed & 15 & 13.4 \\
\hline & Self-Employed & 13 & 11.6 \\
\hline & $\begin{array}{l}\text { Working in a Government / } \\
\text { Public Institution }\end{array}$ & 25 & 22.3 \\
\hline & Working in Private Company & 54 & 48.2 \\
\hline & $\begin{array}{l}\text { Working in a Charity / } \\
\text { Philanthropic Institution }\end{array}$ & 03 & 2.7 \\
\hline
\end{tabular}




\begin{tabular}{|c|c|c|c|}
\hline \multirow{2}{*}{ Attributes } & \multirow{2}{*}{ Category } & \multicolumn{2}{|c|}{ Total } \\
\hline & & $\mathrm{N}$ & $\%$ \\
\hline \multirow{3}{*}{ Work experience } & Less than 1 year & 09 & 8.0 \\
\hline & $1-3$ year & 11 & 9.8 \\
\hline & More than 3 years & 92 & 82.1 \\
\hline \multirow{4}{*}{ Streams } & Business & 82 & 73.2 \\
\hline & Science / Economics & 11 & 9.8 \\
\hline & Engineering & 14 & 12.5 \\
\hline & Others & 5 & 4.5 \\
\hline \multirow{5}{*}{ Location (Continent) } & East Asia and Pacific & 41 & 36.6 \\
\hline & Europe & 14 & 12.5 \\
\hline & North and South America & 06 & 5.4 \\
\hline & Middle East and North Africa & 42 & 37.5 \\
\hline & South Asia & 09 & 8.0 \\
\hline
\end{tabular}

\subsection{Behavioral profile of LinkedIn users}

The behavioural profile of respondents are presented graphically in Figure 2. As per report (Statista, 2018), about 42\% of the LinkedIn users have 300-999 connections. This means that the results of this study represent the actual distribution in terms of number of 1 st connections. In terms of usage, the highest number of users belong to the category who use LinkedIn 10-30 minutes daily $(\mathrm{N}=43,38.4 \%)$. This result is also similar to the usage statistics published by (Statista, 2018). A majority of the respondents in this study reported using LinkedIn for more than 12 months $(\mathrm{N}=100,89.3 \%)$.

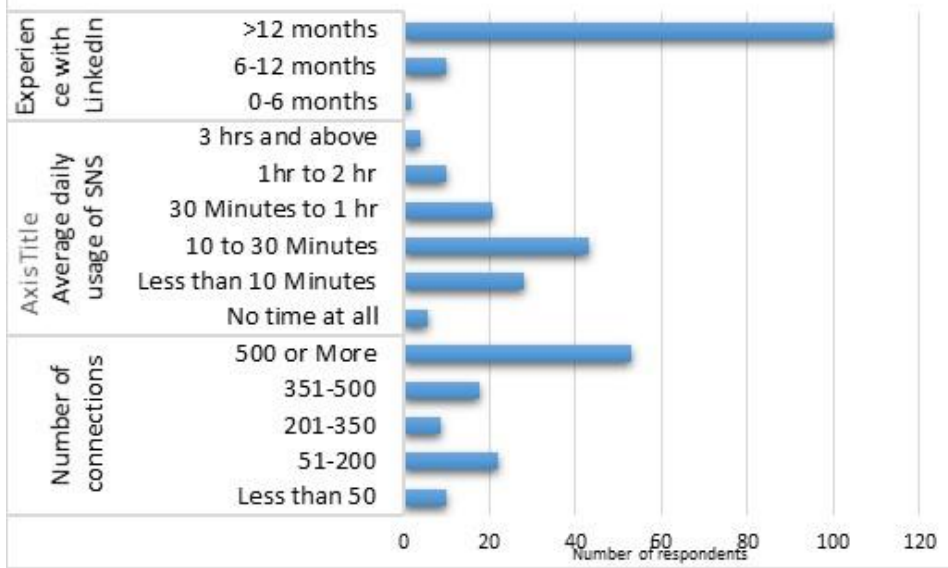

Figure 2. Behavioral profile of LinkedIn Users

\subsection{Testing of model: LinkedIn Usage Intensity and Social Capital}

\subsubsection{Reliability and validity}

The reliability of each construct (variables) is presented in Table 3. Assessment of reliability is done using Cronbach's alpha with recommended value of above 0.7 (Hair et al., 2019; Kock, 2015). The values of Average Variance Extracted (AVE) for all the constructs of the model is above the recommended value of 0.5 (Fornell \& Larcker, 1981; 
J. Hair, et al., 2010). Further the Composite Reliability is also above the threshold of 0.7

(Hair et al., 2010).

Table 3. Reliability and validity

\begin{tabular}{|c|c|c|c|c|c|c|}
\hline Constructs & R2 & Block Communality & Mean Redundancy & $\alpha$ & C.R. & AVE \\
\hline SNSUI & -- & 0.68 & 0.00 & 0.88 & 0.91 & 0.67 \\
\hline BOSC & 0.47 & 0.41 & 0.19 & 0.82 & 0.87 & 0.41 \\
\hline BRSC & 0.48 & 0.68 & 0.33 & 0.95 & 0.96 & 0.69 \\
\hline
\end{tabular}

\subsubsection{Correlation Analysis}

The table (Table 4) below is the correlation matrix in the lower-triangular format, which shows the correlation among the latent variables. It is evident that the correlation $(>0.5)$ among the constructs of the Model is strong.

Table 4. Correlation analysis

\begin{tabular}{|l|l|l|l|}
\hline Construct & & & \\
\hline BrSC & 0.804 & & \\
\hline BoSC & 0.645 & 0.728 & \\
\hline SNSUI & 0.512 & 0.463 & 0.824 \\
\hline
\end{tabular}

\subsubsection{Structural model path and testing of hypothesis}

The assessment of structural relations explain the adequacy of the model as well as the significance of each hypothesized relationship in the model. The strength of each path is measured through a beta value $(\beta)$ in PLS. All the hypotheses for the model have been accepted (Table 5).

Table 5. Structural model path coefficients

\begin{tabular}{|l|c|c|c|c|}
\hline \multirow{2}{*}{ Path } & \multirow{2}{*}{\begin{tabular}{c} 
p-value \\
\cline { 3 - 5 }
\end{tabular}} & $(\mathrm{sig}<0.05)$ & \multicolumn{3}{|c|}{ Causal Effect } \\
\hline SNSUI $\rightarrow$ Bridging Social Capital & $0.00^{*}$ & 0.37 & 0.27 & 0.64 \\
\hline SNSUI $\rightarrow$ Bonding Social Capital & $0.00^{*}$ & 0.69 & 0.00 & 0.69 \\
\hline Bonding Social Capital $\rightarrow$ Bridging Social Capital & $0.00^{*}$ & 0.39 & 0.00 & 0.39 \\
\hline
\end{tabular}

The quality of a structural model is determined by the model fit indices namely average $\mathrm{R}$ squared $\left(\mathrm{R}^{2}\right)$, Average path coefficient and Tenenhaus goodness of fit(Kock, 2015)(Kock, 2015)(Kock, 2015)(Kock, 2015)(Kock, 2015)(Kock, 2015)(Kock, 2015)(Kock, 2015). As per the standards, the GoF value of 0.52 found for the model is satisfactory (Kock, 2015; Wetzels et al., 2009).

\section{Discussions}

The results suggest that the demographic profile of LinkedIn users (age, education and work experience) are partly conforming to the actual population distribution. These are justified as LinkedIn is a professional SNS that primarily attracts users for career advancement and professional growth (Newberry, 2016). Gender and location of users are two important variables that were found to be differing from the reported trends. The 
behavioural profile of the respondents were resembling the past studies (Pang, 2018b, 2018a) and industry reports (Iqbal, 2020). In this study we found that, in line with the reports, majority of respondents reported to have more than 500 connections.

Based on the results obtained by applying PLS-SEM, we found that the model satisfactorily explains the relationship between the constructs and has satisfactory goodness of fit. Our study confirms that SNS usage results in both types of social capital (Bano et al., 2019; Guo et al., 2014; Pang, 2018b).

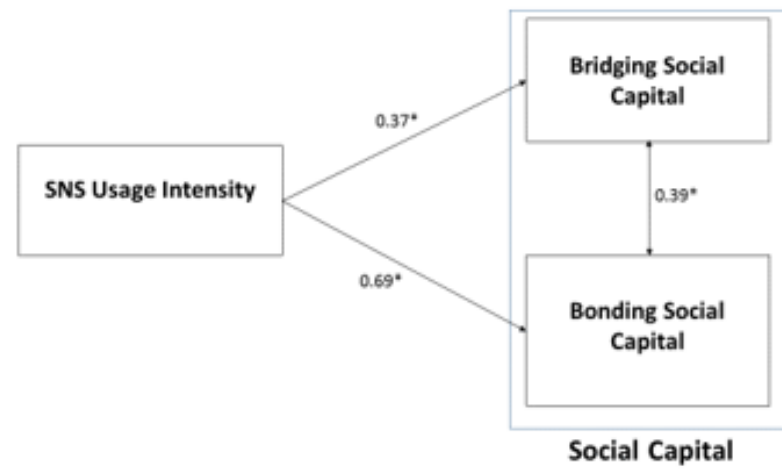

Figure 3. Analyzed Model

\section{Conclusions}

The distinctive feature of this study is that it contributes to the very few research on SNS other than Facebook. Further it also confirms that SNS usage affects both type of capital. Therefore, this study is an extension as well as validation of the theory of social capital in SNS. The demographic and behavioural profile of the users throw some new light to the various dimensions of LinkedIn usage. The research confirmed that like Facebook, LinkedIn usage too positively affects the formation of social capital. Therefore, this study reiterate the potential of SNS for its users as a beneficial resource. The results would provide researchers explore more facets of the social capital formation among LinkedIn users. It would also benefit the industry as well as academic institutions in supporting beneficial uses of SNS. Social capital as a tangible resource is already being studied (Saxton \& Guo, 2020). The role of demographic and behavioural profile of LinkedIn users as a mediating or direct influence on social capital formation is an interesting area for future research. The main limitation of the study is that the sample size is not representing the total population. An improvement in sample size as well as distribution would make the results more generalizable.

\section{References}

Ahmad, S., Mustafa, M., \& Ullah, A. (2016). Association of demographics, motives and intensity of using Social Networking Sites with the formation of bonding and bridging social capital in Pakistan. Computers in Human Behavior, 57, 107-114. https://doi.org/10.1016/j.chb.2015.12.027 
Ali, A., Wang, H., \& Khan, A. N. (2019). Mechanism to enhance team creative performance through social media: A Transactive memory system approach. Computers in Human Behavior, 91, 115-126. https://doi.org/10.1016/j.chb.2018.09.033

Appel, L., Dadlani, P., Dwyer, M., Hampton, K., Kitzie, V., Matni, Z. A., .. Teodoro, R. (2014). Testing the validity of social capital measures in the study of information and communication technologies. Information Communication and Society, 17(4), 398-416. https://doi.org/10.1080/1369118X.2014.884612

Arampatzi, E., Burger, M. J., \& Novik, N. (2018). Social Network Sites, Individual Social Capital and Happiness. Journal of Happiness Studies, 19(1), 99-122. https://doi.org/10.1007/s10902-016-9808-z

Bano, S., Cisheng, W., Khan, A. N., \& Khan, N. A. (2019). WhatsApp use and student's psychological wellbeing: Role of social capital and social integration. Children and Youth Services Review, 103(June), 200208. https://doi.org/10.1016/j.childyouth.2019.06.002

Bourdieu, P., \& Wacquant, L. J. (1992). The purpose of reflexive sociology (The Chicago Workshop. In An invitation to reflexive sociology.

Boyd, D. M., \& Ellison, N. B. (2007). Social network sites: Definition, history, and scholarship. Journal of Computer-Mediated Communication, 13(1), 210-230. https://doi.org/10.1111/j.10836101.2007.00393.x

Brown, G., \& Michinov, N. (2019). Measuring latent ties on Facebook: A novel approach to studying their prevalence and relationship with bridging social capital. Technology in Society, 59(September 2017), 101176. https://doi.org/10.1016/j.techsoc.2019.101176

Burke, M., \& Kraut, R. E. (2016). The Relationship between Facebook Use and Well-Being depends on Communication Type and Tie Strength. Journal of Computer-Mediated Communication, 21(4), 265-281. https://doi.org/10.1111/jcc4.12162

Chang, Y. P., \& Zhu, D. H. (2012). The role of perceived social capital and flow experience in building users' continuance intention to social networking sites in China. Computers in Human Behavior, 28(3), 9951001. https://doi.org/10.1016/j.chb.2012.01.001

Cheng, C., Wang, H. Y., Sigerson, L., \& Chau, C. L. (2019). Do the socially rich get richer? A nuanced perspective on social network site use and online social capital accrual. Psychological Bulletin, 145(7), 734-764. https://doi.org/10.1037/bul0000198

Darcy, S., Maxwell, H., Edwards, M., Onyx, J., \& Sherker, S. (2014). More than a sport and volunteer organisation: Investigating social capital development in a sporting organisation. Sport Management Review, 17(4), 395-406. https://doi.org/10.1016/j.smr.2014.01.003

De Carolis, D. M., Litzky, B. E., \& Eddleston, K. A. (2009). Why networks enhance the progress of new venture creation: The influence of social capital and cognition. Entrepreneurship: Theory and Practice, 33(2), 527-545. https://doi.org/10.1111/j.1540-6520.2009.00302.x

Edwards, B., Foley, M. W., \& Putnam, R. D. (2001). Much Ado about Social CapitalBowling Alone: The Collapse and Revival of American Community. Contemporary Sociology, 30(3), 227. https://doi.org/10.2307/3089235

Edwards, S. M. (2011). A Social Media Mindset. Journal of Interactive Advertising, 12(1), 1-3. https://doi.org/10.1080/15252019.2011.10722186

Ellison, N. B., Steinfield, C., \& Lampe, C. (2007). The benefits of facebook "friends:" Social capital and college students' use of online social network sites. Journal of Computer-Mediated Communication, 12(4), 11431168. https://doi.org/10.1111/j.1083-6101.2007.00367.x

Ellison, N. B., Steinfield, C., \& Lampe, C. (2011). Connection strategies: Social capital implications of Facebook-enabled communication practices. New Media and Society, 13(6), 873-892. https://doi.org/10.1177/1461444810385389

Ellison, N. B., \& Vitak, J. (2015). Social Network Site Affordances and Their Relationship to Social Capital Processes. In The Handbook of the Psychology of Communication Technology (pp. 203-227). https://doi.org/10.1002/9781118426456.ch9

Ellison, N. B., Vitak, J., Gray, R., \& Lampe, C. (2014). Cultivating social resources on social network sites: Facebook relationship maintenance behaviors and their role in social capital processes. Journal of Computer-Mediated Communication, 19(4), 855-870. https://doi.org/10.1111/jcc4.12078

Farr, J. (2004). Social Capital: A Conceptual History. Political Theory, Vol. 32, pp. 6-33. https://doi.org/10.1177/0090591703254978

Finstad, K. (2010). Response interpolation and scale sensitivity: Evidence against 5-point scales. Journal of Usability Studies, 5(3), 104-110. 
Fornell, C., \& Larcker, D. F. (1981). Evaluating Structural Equation Models with Unobservable Variables and Measurement Error. Journal of Marketing Research, 18(1), 39. https://doi.org/10.2307/3151312

Guo, Y., Li, Y., \& Ito, N. (2014). Exploring the predicted effect of social networking site use on perceived social capital and psychological well-being of Chinese international students in Japan. Cyberpsychology, Behavior, and Social Networking, 17(1), 52-58. https://doi.org/10.1089/cyber.2012.0537

Haghighatian, M., \& Sanatkhah, A. (2014). The relationship between bonding and bridging social capital and residents' support of domestic production in the city of Kerman, Iran. Advances in Environmental Biology, 8(6 SPEC. ISSUE 2), 1528-1532.

Hair, J., Black, W., Babin, B., \& Anderson, R. (2010). Multivariate Data Analysis: A Global Perspective. In Multivariate Data Analysis: A Global Perspective (Vol. 7th).

Hair, J. F., Ringle, C. M., Gudergan, S. P., Fischer, A., Nitzl, C., \& Menictas, C. (2019). Partial least squares structural equation modeling-based discrete choice modeling: an illustration in modeling retailer choice. Business Research, 12(1), 115-142. https://doi.org/10.1007/s40685-018-0072-4

Hamilton, J. (2007). Service value networks: Into practice. Journal of Systems Science and Systems Engineering, 16(4), 414-423. https://doi.org/10.1007/s11518-007-5057-3

Haythornthwaite, C. (2002). Strong, weak, and latent ties and the impact of new media. Information Society, 18(5), 385-401. https://doi.org/10.1080/01972240290108195

Horng, S. M., \& Wu, C. L. (2020). How behaviors on social network sites and online social capital influence social commerce intentions. Information and Management, 57(2). https://doi.org/10.1016/j.im.2019.103176

Huang, L. V., \& Liu, P. L. (2017). Ties that work: Investigating the relationships among coworker connections, work-related Facebook utility, online social capital, and employee outcomes. Computers in Human Behavior, 72, 512-524. https://doi.org/10.1016/j.chb.2017.02.054

Humphreys, L. (2007). Mobile social networks and social practice: A case study of dodgeball. Journal of Computer-Mediated Communication, 13(1), 341-360. https://doi.org/10.1111/j.10836101.2007.00399.x

Iqbal, M. (2020). LinkedIn Usage and Revenue Statistics (2020). Retrieved August 2, 2020, from BusinessofApps website: https://www.businessofapps.com/data/linkedin-statistics/

Kahai, S. S., \& Lei, Y. (2019). Building social capital with Facebook: Type of network, availability of other media, and social self-efficacy matter\#. International Journal of Human Computer Studies, 130(March 2018), 113-129. https://doi.org/10.1016/j.ijhcs.2019.05.013

Kaplan, A. M., \& Haenlein, M. (2010). Users of the world, unite! The challenges and opportunities of Social Media. Business Horizons, 53(1), 59-68. https://doi.org/10.1016/j.bushor.2009.09.003

Kellogg, K. (2020). The 7 Biggest Social Media Sites in 2020. Retrieved July 31, 2020, from Search Engine Journal website: https://www.searchenginejournal.com/social-media/biggest-social-media-sites/

Kietzmann, J. H., Hermkens, K., McCarthy, I. P., \& Silvestre, B. S. (2011). Social media? Get serious! Understanding the functional building blocks of social media. Business Horizons, 54(3), 241-251. https://doi.org/10.1016/j.bushor.2011.01.005

Kock, N. (2015). A note on how to conduct a factor-based PLS-SEM analysis. International Journal of ECollaboration, 11(3), 1-9. https://doi.org/10.4018/ijec.2015070101

Kwon, S. W., \& Adler, P. S. (2014). Social capital: Maturation of a field of research. Academy of Management Review, 39(4), 412-422. https://doi.org/10.5465/amr.2014.0210

Lee, E., Kim, Y. J., \& Ahn, J. (2014). How do people use Facebook features to manage social capital? Computers in Human Behavior, 36, 440-445. https://doi.org/10.1016/j.chb.2014.04.007

Lin, N. (2019). Building a network theory of social capital. In Social Capital, Social Support and Stratification: An Analysis of the Sociology of Nan Lin (pp. 50-76). https://doi.org/10.4324/9781315129457-1

Liu, D., Ainsworth, S. E., \& Baumeister, R. F. (2016). A meta-analysis of social networking online and social capital. Review of General Psychology, 20(4), 369-391. https://doi.org/10.1037/gpr0000091

Lőrincz, L., Koltai, J., Győr, A. F., \& Takács, K. (2019). Collapse of an online social network: Burning social capital to create it? Social Networks, 57(December 2018), 43-53. https://doi.org/10.1016/j.socnet.2018.11.004

Mateos-Aparicio, G. (2011). Partial least squares (PLS) methods: Origins, evolution, and application to social sciences. Communications in Statistics - Theory and Methods, 40(13), 2305-2317. https://doi.org/10.1080/03610921003778225

Nahapiet, J., \& Ghoshal, S. (2009). Social capital, intellectual capital, and the organizational advantage. In Knowledge and Social Capital (pp. 119-158). https://doi.org/10.2307/259373 
Neves, B. B. (2013). Social capital and internet use: The irrelevant, the bad, and the good. Sociology Compass, 7(8), 599-611. https://doi.org/10.1111/soc4.12059

Newberry, C. (2016). Top Snapchat Demographics That Matter to Social Media Marketers. Retrieved July 25, 2020, from Hootsuite website: https://blog.hootsuite.com/snapchat-demographics/

Pang, H. (2017). Is smartphone creating a better life? Exploring the relationships of the smartphone practices, social capital and psychological well-being among college students. International Journal of Advanced Media and Communication, 7(3), 205-223. https://doi.org/10.1504/IJAMC.2017.089346

Pang, H. (2018a). Exploring the beneficial effects of social networking site use on Chinese students' perceptions of social capital and psychological well-being in Germany. International Journal of Intercultural Relations, 67(August), 1-11. https://doi.org/10.1016/j.ijintrel.2018.08.002

Pang, H. (2018b). How does time spent on WeChat bolster subjective well-being through social integration and social capital? Telematics and Informatics, 35(8), 2147-2156. https://doi.org/10.1016/j.tele.2018.07.015

Papathanassopoulos, S. (2011). Media perspectives for the 21st century. In Media Perspectives for the 21st Century (pp. 1-248). https://doi.org/10.4324/9780203834077

Petersen, C., \& Johnston, K. A. (2015). The impact of social media usage on the cognitive social capital of university students. Informing Science, 18(1), 1-31.

Phua, J., Jin, S. V., \& Kim, J. (Jay). (2017). Uses and gratifications of social networking sites for bridging and bonding social capital: A comparison of Facebook, Twitter, Instagram, and Snapchat. Computers in Human Behavior, 72, 115-122. https://doi.org/10.1016/j.chb.2017.02.041

Resnick, P. (2001). Beyond Bowling Together: SocioTechnical Capital. Human-Computer Interaction in the New Millenium, 77(March), 247-272. https://doi.org/Can't find

Saxton, G. D., \& Guo, C. (2020). Social media capital: Conceptualizing the nature, acquisition, and expenditure of social media-based organizational resources. International Journal of Accounting Information Systems, 36, 100443. https://doi.org/10.1016/j.accinf.2019.100443

Song, Y., \& Vinig, T. (2012). Entrepreneur online social networks - structure, diversity and impact on start-up survival. International Journal of Organisational Design and Engineering, 2(2), 189. https://doi.org/10.1504/ijode.2012.047574

Statista. (2018). Interesting statistics on the number of LinkedIn connections per user! Retrieved July 30, 2020, from Statista website: https://www.linkedin.com/pulse/interesting-statistics-number-linkedinconnections-per-lionel-anciaux/

Statista. (2020). Number of social network users worldwide from 2017 to 2025. Retrieved from Statista website: https://www.statista.com/statistics/278414/number-of-worldwide-social-network-users/

Steinfield, C., DiMicco, J. M., Ellison, N. B., \& Lampe, C. (2009). Bowling online. C\&T '09 Proceedings of the Fourth International Conference on Communities and Technologies, 245. https://doi.org/10.1145/1556460.1556496

Steinfield, C., Ellison, N. B., \& Lampe, C. (2008). Social capital, self-esteem, and use of online social network sites: A longitudinal analysis. Journal of Applied Developmental Psychology, 29(6), 434-445. https://doi.org/10.1016/j.appdev.2008.07.002

Subrahmanyam, K., Reich, S. M., Waechter, N., \& Espinoza, G. (2008). Online and offline social networks: Use of social networking sites by emerging adults. Journal of Applied Developmental Psychology, 29(6), 420-433. https://doi.org/10.1016/j.appdev.2008.07.003

Svendsen, G. L. H., \& Svendsen, G. T. (2003). On the wealth of nations: Bourdieuconomics and social capital. Theory and Society, Vol. 32, pp. 607-631. https://doi.org/10.1023/B:RYSO.0000004967.97783.c4

Tina Yuan, C. W., Hanrahan, B. V., \& Carroll, J. M. (2018). Is there social capital in service exchange tools?: Investigating timebanking use and social capital development. Computers in Human Behavior, 81, 274 281. https://doi.org/10.1016/j.chb.2017.12.029

Tiwari, S., Lane, M., \& Alam, K. (2019). Do social networking sites build and maintain social capital online in rural communities? Journal of Rural Studies, 66, 1-10. https://doi.org/10.1016/j.jrurstud.2019.01.029

Treem, J. W., \& Leonardi, P. M. (2012). Social Media Use in Organizations: Exploring the Affordances of Visibility, Editability, Persistence, and Association. SSRN Electronic Journal. https://doi.org/10.2139/ssrn.2129853

Vanden Abeele, M. M. P., Antheunis, M. L., Pollmann, M. M. H., Schouten, A. P., Liebrecht, C. C., van der Wijst, P. J., ... Maes, F. A. (2018). Does Facebook Use Predict College Students' Social Capital? A Replication of Ellison, Steinfield, and Lampe's (2007) Study Using the Original and More Recent Measures of Facebook Use and Social Capital. Communication Studies, 69(3), 272-282. https://doi.org/10.1080/10510974.2018.1464937 
Wang, T., Yeh, R. K. J., Chen, C., \& Tsydypov, Z. (2016). What drives electronic word-of-mouth on social networking sites? Perspectives of social capital and self-determination. Telematics and Informatics, 33(4), 1034-1047. https:// doi.org/10.1016/j.tele.2016.03.005

Weiqin, E. L., Campbell, M., Kimpton, M., Wozencroft, K., \& Orel, A. (2016). Social Capital on Facebook. Journal of Educational Computing Research, 54(6), 747-768. https://doi.org/10.1177/0735633116631886

Wellman, B., Quan Haase, A., Witte, J., \& Hampton, K. (2001). Does the Internet increase, decrease, or supplement social capital? Social networks, participation, and community commitment. American Behavioral Scientist, (3), 436-455. https://doi.org/10.1177/00027640121957286

Wetzels, M., Odekerken-Schröder, G., \& Van Oppen, C. (2009). Using PLS path modeling for assessing hierarchical construct models: Guidelines and empirical illustration. MIS Quarterly: Management Information Systems, 33(1), 177-196. https://doi.org/10.2307/20650284

Williams, D. (2006). On and off the 'Net: Scales for Social Capital in an Online Era. Journal of Computer-Mediated Communication, 11(2), 593-628. https://doi.org/10.1111/j.1083-6101.2006.00029.x

Williams, J. R. (2019). The use of online social networking sites to nurture and cultivate bonding social capital: A systematic review of the literature from 1997 to 2018. New Media and Society, 21(11-12), 27102729. https://doi.org/10.1177/1461444819858749

Yoo, J. H., \& Jeong, E. J. (2017). Psychosocial effects of SNS use: A longitudinal study focused on the moderation effect of social capital. Computers in Human Behavior, 69, 108-119. https://doi.org/10.1016/j.chb.2016.12.011

You, L., \& Hon, L. (2019). How social ties contribute to collective actions on social media: A social capital approach. Public Relations Review, 45(4), 101771. https://doi.org/10.1016/j.pubrev.2019.04.005 